\title{
Exploring Factors Influencing Species Natural Regeneration Response Following Harvesting in the Acadian Forests of New Brunswick
}

\author{
Lee Salmon'1, John A. Kershaw Jr. ${ }^{1 *}$, Anthony R. Taylor', Marek Krasowski', \\ Michael B. Lavigne ${ }^{2}$ \\ ${ }^{1}$ Faculty of Forestry and Environmental Management, University of New Brunswick, Fredericton, Canada \\ ${ }^{2}$ Natural Resources Canada, Canadian Forest Service-Atlantic Forestry Centre, Fredericton, Canada \\ Email: ${ }^{*}$ kershaw@unb.ca
}

Received 10 May 2016; accepted 18 June 2016; published 22 June 2016

Copyright @ 2016 by authors and Scientific Research Publishing Inc. This work is licensed under the Creative Commons Attribution International License (CC BY). http://creativecommons.org/licenses/by/4.0/

c) (i) Open Access

\begin{abstract}
In the Acadian Forest Region of northeastern North America, forest managers are under increasing public pressure to restore the forest to a more historic, natural condition by reducing in clearcutting and promoting partial-cut treatments that more closely emulate historic, local natural disturbance regimes. However, although numerous studies on the effects of partial-cutting on forest regeneration response have been conducted in surrounding temperate and boreal forest ecosystems, there are few studies that directly explore responses to various forms of harvesting within the Acadian Forest ecosystem, with its unique mixture of northern hardwoods and boreal forest species. Here, we conducted one of the first retrospective studies on forest regeneration following a variety of harvesting methods in the Acadian Forest using univariate and multivariate regression trees to assess regeneration response in $\mathbf{5 0}$ naturally-regenerating, harvested forest sites in New Brunswick, Canada. Our study shows that regeneration was highly influenced by harvest type, overstory composition, and environmental conditions as reflected by ecoregion classification. Canopy opening size (as controlled by harvest method) significantly influenced the dominance of regenerating species. The presence of conspecific overstory trees increased the likelihood of their regeneration following disturbance, supporting the direct-regeneration hypothesis, especially for species with limited seed dispersal (e.g., sugar maple (Acer saccharum Marsh.) and American beech (Fagus grandifolia Ehrh.). Despite reported problems elsewhere in eastern North America, neither American beech nor balsam fir (Abies balsamea (L.) Mill.) constituted significant competition for the desired species on a broad scale, but the presence of beech was a significant deterrent for yellow birch (Betula alleghaniensis Britt.).
\end{abstract}

\footnotetext{
${ }^{*}$ Corresponding author.
} 


\section{Keywords}

\section{Tolerant Hardwood Management, Regeneration Dynamics, Time Since Harvest, Opening Size, Residual Overstory, Acadian Forest Region, Regression Trees}

\section{Introduction}

The Acadian Forest of northeastern North America represents an ecotone between the more temperate northern hardwood forest and the boreal forest (Rowe, 1972). The pre-European state of the Acadian Forest is considered to have been mixed coniferous and deciduous forests with long durations (>250 - 1000 years) between largescale, stand-replacing disturbances (Mosseler et al., 2003; Seymour et al., 2002). Since the arrival of Europeans, the Acadian Forest has been subjected to wide-scale land clearance and subsequent land abandonment, major wildfires following logging, and varying intensities of harvesting activities (Betts \& Loo, 2002; Loo \& Ives, 2003). In New Brunswick, Canada, over much of the past 40 years, forest management strategies have emphasized large-scale industrial forest management (Simpson, 2009), with a major focus on coniferous forest plantations. Although conversion of hardwood stands to coniferous plantations has declined since the early 1990s (Floyd et al., 2012), many of the forest management practices, especially wide-spread use of clearcutting, have increased balsam fir (Abies balsamea (L.) Mill.) and red maple (Acer rubrum L.) components (Lees, 1981, 1978; Salonius, 2007).

Despite decades of research (e.g., Clements, 1916; Drury \& Nisbet, 1973; Oliver \& Larson, 1996; Walker et al., 2010), forest dynamics remains an important research area of forest ecosystem management (Bose et al., 2014; Brais et al., 2013; Harvey et al., 2002; Kuuluvainen \& Grenfell, 2012). Disturbances, including timber harvesting, alter the distribution and abundance of plants in forest stands by changing the environment and creating opportunities for establishment of regeneration (Oliver \& Larson, 1996). Although the patterns and processes of plant community reorganization and assembly following disturbances are generally well recognized (Christensen et al., 1996; Oliver, 1981; White, 1979), specific outcomes and the interactions between underlying causal mechanisms remain unclear (Levin, 1992; Rai, 2013; Zeide, 1999).

When managing mixed-species stands, harvesting has the potential to alter the species favored as regeneration (Leak \& Filip, 1977; Carlson \& Groot, 1997; Arseneault et al., 2011). However, predicting which tree communities will arise following harvesting remains a difficult task (Roberts \& Gilliam, 1995; Gould et al., 2005), especially in mixed-species stands (Bataineh et al., 2013). Important factors that influence specific outcomes following disturbance include: species present before a disturbance, altered light conditions, competitive interactions between species, and species-specific physiological responses to soil and climate (Oliver, 1981; Huston \& Smith, 1987; Chapin et al., 1994; Greene et al., 1999).

Retention of seed trees, advanced regeneration, and existing seed banks encourage particular species to regenerate following forest harvesting (Nyland, 1996; Smith et al., 1997), but they do not guarantee predictable development of regenerating stands (Bataineh et al., 2013; Jones et al., 1989; Loftis, 1983). Light availability, dictated by canopy shading, significantly affects the dynamics of understory regeneration, helping to control species composition and density (Logan, 1965; Marquis, 1967, 1979; Dale et al., 1995; Raymond et al., 2006). Because regenerating tree species differ in their growth strategies in response to available light (Logan, 1965), their dominance relative to each other changes over time (Cattelino et al., 1979; Noble \& Slatyer, 1980; Martin \& Hornbeck, 1989), adding to the difficulty of predicting successive cohorts.

Although forest management activities alter the available light and, thus, the species present, variations in topography, climate, and soils also affect forest dynamics (Trimble, 1973; Williams \& Heiligmann, 2003), and, ultimately, the patterns of secondary succession (Taylor \& Chen, 2011; Longpre \& Morris, 2012). Climate also broadly controls species distributions (Sexton et al., 2009; McGill, 2010); however, local geographic variations in site resources and conditions alter community dynamics and species composition (Ricklefs, 2004; Swenson et al., 2012). Thus, forest management must consider local environmental factors when designing silvicultural interventions.

Studies on the effects of forest harvesting in mixed stands within the nearby northern hardwood forests of northeastern North America have examined biotic and abiotic factors influencing successful regeneration and 
recruitment of various species (Archambault et al., 2009; Engelman \& Nyland, 2006; Gilbert \& Jensen, 1958; Leak, 2006a, 2005, 1996; Leak \& Filip, 1977; Matonis et al., 2011); however, the abundance of balsam fir and red maple, and the intense infestation of American beech (Fagus grandifolia Ehrh.) with beech bark disease (Taylor et al., 2013) reduce direct comparability of these studies to the Acadian Forest where these issues are more of a concern (Arseneault et al., 2011; Morin et al., 2007). The reduction of shade-tolerant hardwood species within the Acadian Forest (Loo \& Ives, 2003; Salonius, 2007) calls into question presently used harvesting methods and their effects on the establishment and recruitment of these tree species, yet there is currently limited local empirical knowledge to support changes in forest management policy or practices (Floyd et al., 2012).

To address this gap, we conducted a retrospective analysis of harvested stands across New Brunswick to explore effects of silviculture and environmental variables on tree species regeneration dynamics. Specifically, we explored the influence of overstory species composition and harvesting treatments, as well as time since harvest and ecoregion, to identify key mechanisms that influence tolerant hardwood regeneration dynamics. Because of the opportunistic nature of our sample design, the lack of independent control sites, and the inherent pseudoreplication in such studies, we employed robust statistical techniques, specifically univariate and multivariate regression trees, to explore and identify key factors influencing species composition and dominance across the sites sampled in this study.

\section{Methods}

\subsection{Study Area}

Data were collected from 50 sites across northwestern and central New Brunswick, Canada (Figure 1). The province of New Brunswick has a mixed continental-maritime climate primarily influenced by westerly continental air masses and Atlantic oceanic weather systems (Environment Canada, 2013; Government of Canada, 1962). New Brunswick's climate is moderated by the Bay of Fundy to the south and the Gulf of St. Lawrence to the east, whereas inland regions (e.g., the northwestern parts of the province) have more continental climates, and this variation and mix of air masses create diverse climates and soil types in a relatively small jurisdiction (Colpitts, 1995). New Brunswick lies within the Acadian Forest Region (Rowe, 1972), with approximately 32 tree species characteristic of temperate and boreal forest regions. Red spruce (Picea rubens Sarg.) is generally considered to be the defining tree species of the region, but mixed stands of northern and southern species are typical of Acadian Forest conditions. Southerly species include sugar maple (Acer saccharum Marsh.), red maple, yellow birch (Betula alleghaniensis Britt.), American beech, white ash (Fraxinus americana L.), eastern hemlock (Tsuga canadensis (L.) Carrière), and eastern white pine (Pinus strobus L.). Northerly boreal species in the Acadian Forest include white birch (Betula papyrifera Marshall), trembling aspen (Populus tremuloides Michx.), tamarack (Larix laricina K. Koch), balsam fir, black spruce (Picea mariana (Mill.) B.S.P.), and white spruce (Picea glauca (Moench) Voss).

We surveyed harvested stands from four ecoregions (Zelazny et al., 2003) across New Brunswick (Figure 1); the Highlands, Northern Uplands, Central Uplands, and Eastern Lowlands. The Highlands and Northern Uplands are dominated by boreal coniferous and deciduous species, except along valleys and ridge slopes where more southerly species, like sugar maple, yellow birch, and occasionally beech, occur. The Central Uplands' undulating terrain supports tolerant hardwood and southerly conifer species on ridges and slopes, and northerly conifers are less frequent. The Highlands, Northern Uplands, and Central Uplands are part of the northern reaches of the Appalachian mountain range, and they have relatively well-developed soils and many welldrained sites. Compared with the other three ecoregions, the Eastern Lowlands have very low relief, resulting in wetter and less fertile soils supporting primarily coniferous species, but nutrient rich and better drained sites can support tolerant hardwood species.

Sample sites were identified using the New Brunswick Department of Natural Resources (NBDNR) GIS database and were selected across the range of tolerant hardwood content ( $>40 \%$ composition), past harvest treatment, and time since harvest (TSH). Harvest treatments examined included: clearcutting (CC), which includes complete overstory removal in areas $>2$ ha in size and $>20$ m wide; seed tree and shelterwood regeneration cuts (RC), which include at least $50 \%$ basal area removal of the overstory in areas $>2$ ha in size and $>20 \mathrm{~m}$ wide; circular patch cuts (PA) ( $\sim 10$ - 20 m radius); systematic strip cuts (SS) ( $\sim 5 \mathrm{~m}$ cut width); and single-tree selection (SC) (maximum of $30 \%$ basal area removal). All sample stands regenerated naturally after harvest treatment 
without any additional silvicultural intervention (i.e., planting or weeding).To facilitate field logistics, clusters of potential stands were identified where the greatest diversity of stand type $\times$ harvest treatment $\times$ TSH could be located (Figure 1). In total, 50 sites were selected from four different clusters, with a total of 307 sample points (Table 1).

\subsection{Stand-Level Sample Design}

Sample points were selected for each stand using ArcGIS 9.3 (Environmental Systems Resource Institute, Redlands, CA) and the 50m systematic Forest Development Survey (FDS) sample grid developed by NBDNR (Adam Dick, NBDNR Timber Management, pers. comm.). Sample points were selected from the FDS grid using aerial photographs to stratify stands and ensure a full range of stand conditions were sampled. Plot layout varied depending on harvest type. For the CC, RC, and SC harvests, single nested plots were selected throughout the stand, and the FDS grid points were used as sample point locations. For the PA and SS treatments, sample points were located in areas where harvesting occurred. Sample points in the SC within non-harvested areas were omitted from this analysis. At each sample point, nested plots were used to sample the overstory trees, saplings, and seedlings.

Table 1. Number of plots sampled across ecoregions, treatments, and time classes (TSH).

\begin{tabular}{|c|c|c|c|c|c|c|c|}
\hline \multirow{2}{*}{ Ecoregion } & \multirow{2}{*}{$\begin{array}{c}\text { Time Since } \\
\text { Harvest (years) }\end{array}$} & \multicolumn{5}{|c|}{ Harvest Treatment Type ${ }^{1}$} & \multirow{2}{*}{ Total } \\
\hline & & SS & SC & PA & $\mathrm{RC}$ & CC & \\
\hline \multirow{5}{*}{ Highlands } & $0-10$ & 40 & & & 3 & 3 & 46 \\
\hline & $11-20$ & & 5 & & & 11 & 16 \\
\hline & $21-30$ & & 8 & & & & 8 \\
\hline & $\geq 31$ & & 3 & & & & 3 \\
\hline & Subtotal & 40 & 16 & 0 & 3 & 14 & 73 \\
\hline \multirow{6}{*}{ Central Uplands } & $0-10$ & 8 & & & 2 & 3 & 13 \\
\hline & $11-20$ & & 10 & 15 & 4 & 9 & 38 \\
\hline & $21-30$ & & & & 3 & 4 & 7 \\
\hline & $\geq 31$ & & & & & & 0 \\
\hline & Subtotal & 8 & 10 & 15 & 9 & 16 & 58 \\
\hline & $0-10$ & 22 & 16 & & & 5 & 43 \\
\hline \multirow{4}{*}{ Northern Uplands } & $11-20$ & 10 & 28 & & & & 38 \\
\hline & $21-30$ & & 22 & & & 3 & 25 \\
\hline & $\geq 31$ & & 15 & & & & 15 \\
\hline & Subtotal & 32 & 81 & 0 & 0 & 8 & 121 \\
\hline \multirow{5}{*}{ Eastern Lowlands } & $0-10$ & 4 & & 14 & & & 18 \\
\hline & $11-20$ & & 7 & 30 & & & 37 \\
\hline & $21-30$ & & & & & & 0 \\
\hline & $\geq 31$ & & & & & & 0 \\
\hline & Subtotal & 4 & 7 & 44 & 0 & 0 & 55 \\
\hline Total & & 84 & 114 & 59 & 12 & 38 & 307 \\
\hline
\end{tabular}

${ }^{1} \mathrm{SC}=$ Single-tree selection, $\mathrm{SS}=$ strip selection, $\mathrm{PA}=$ circular patch cuts; $\mathrm{RC}=$ seed-tree/shelterwood, $\mathrm{CC}=$ clearcut 


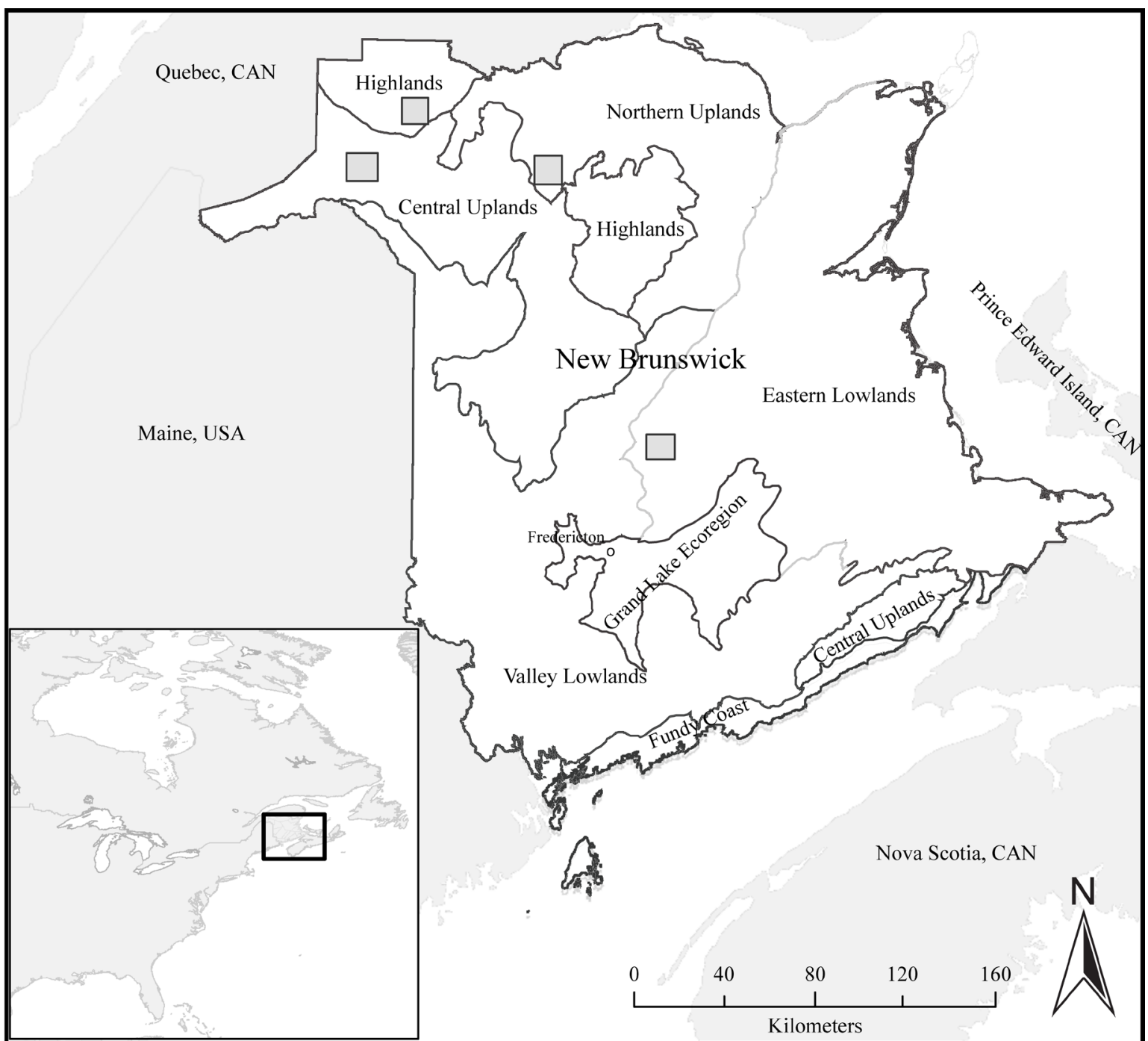

Figure 1. Regional map showing the location of New Brunswick, and the locations of the study clusters (gray rectangles) and ecoregions within New Brunswick, Adapted from Natural Resources Canada

(http://www.nrcan.gc.ca/earth-sciences/geography/topographic-information/maps/9771) and GeoNB (http://geonb.snb.ca/geonb/).

Overstory trees were sampled using horizontal point sampling (Husch et al., 2002) and a 3M BAF angle gauge (each tree tallied represented $3 \mathrm{~m}^{2} \mathrm{ha}^{-1}$ basal area). Using the sample point location, tallied trees were identified by species and status (live or dead), and diameter at breast height (DBH, $1.3 \mathrm{~m}$ above root collar) was measured to the nearest $0.1 \mathrm{~cm}$. In SS cuts, overstory measurements were confined to the residual strips.

Regeneration was recorded from two fixed-area nested plots centered on the sample point. A 0.8-m radius $\left(1 / 5000^{\text {th }}\right.$ ha) regeneration plot was used to record all regeneration between $0.3 \mathrm{~m}$ and $1.3 \mathrm{~m}$ tall using a tally of individuals by species and height class (i.e., $30-54 \mathrm{~cm}, 55-79 \mathrm{~cm}, 80-104 \mathrm{~cm}$ and $105-130 \mathrm{~cm}$ ). A second plot, at the same center point, with a radius of $3.57 \mathrm{~m}\left(1 / 250^{\text {th }}\right.$ ha) was used to sample all sapling-sized regeneration ( $>1.3 \mathrm{~m}$ tall and $<10 \mathrm{~cm}$ DBH). Saplings were recorded using a tally by species and $2 \mathrm{~cm}$ DBH classes (e.g., $0.0-1.9,2.0$ - 3.9, etc.) up to $9.9 \mathrm{~cm}$ DBH. The tallest sapling of each species was measured for height and exact DBH (nearest $0.1 \mathrm{~cm}$ ).

\subsection{Data Analyses}

Overall, we observed 22 tree species across all plots; however, only five species were analyzed individually, 
based on their abundance and perceived value as crop trees or competitors. The 17 less frequent species (occurring in $<20 \%$ of plots) were grouped according to their shade tolerance and/or desirability (i.e., commercial value). Eight species/species groups were used in our analyses: 1) sugar maple (SM); 2) yellow birch (YB); 3) American beech (BE); 4) balsam fir (BF); 5) red maple (RM); 6) tolerant competitors (TOL), which included: striped maple (Acer pennsylvanicum L.), mountain maple (Acer spicatum Lam.), and eastern hemlock; 7) intolerant competitors (ITOL), which included: white birch, poplar (Populus spp.), pin cherry (Prunus pensylvanica L.f.), mountain ash (Sorbus spp.), and willow (Salix spp.); and 8) other commercially desirable species (ODS), which included: white ash, black ash (Fraxinus nigra Marsh.), white spruce, black spruce, red spruce, eastern white pine, and eastern white cedar (Thuja occidentalis L.). The cohort analyzed was composed of seedlings and saplings, except for stands harvested $>30$ years prior to measurement, where it was assumed that any existing seedlings were not part of the initial cohort that resulted from harvesting (thus, only the saplings were analyzed in stands $>30$ years since harvest treatment).

Two response variables were calculated for each species group: relative abundance (RA) and dominance. RA is a measure of plant community structure, specifically a species' representation in the composition of a community, with respect to other species, and was calculated at the plot level:

$$
R A_{i}=100\left(\frac{\text { Density }_{i}}{\sum_{i=1}^{n} \text { Density }_{i}}\right)
$$

where $R A_{i}=$ relative abundance of species group $i$ (\% of density), and Density $y_{\mathrm{i}}=$ stem density of species group $\mathrm{i}$ (trees/ha).

Dominance of each species group was determined from the heights of regenerating tree species. For each plot, the species group with the tallest regenerating tree was considered the dominant species. In the case of ties, all species groups were considered dominant.

Generalized Boosted Regression Models (Ridgeway, 2013) were used to explore and identify variables that substantially influenced RA and dominance of each species group from a pool of 58 potential explanatory variables that included a range of site and stand-level characteristics. Relative influence scores (Ridgeway, 2013) were used to identify each variable's strength of influence. Explanatory variables retained for our final analyses were time since harvest (TSH), ecoregion, harvest type, residual overstory species composition (expressed as a percent of residual basal area) and residual overstory species basal area.

Recursive partitioning (Breiman, 1984), in the form of regression trees, was used to model both RA and dominance responses at the plot level. Regression trees split the sample plots into successively less diverse subsets based on binary splits using our set of explanatory variables. Trees can be assessed for fit by measuring percent deviance explained (DE) by the overall model, as an equivalent to $\mathrm{R}^{2}$ in linear models:

$$
D E=100\left(1-\frac{\text { Residual Deviance }}{\text { Total Deviance }}\right)
$$

Average percentage of the total deviance reduced by specific variables (DevR) also provides a measure of importance for variables in relation to the response variables:

$$
\operatorname{DevR}=100\left(\frac{\mathrm{NDev}-\sum \mathrm{CDev}}{\mathrm{TDev}}\right)
$$

where DevR = percent deviance reduced; NDev = node deviance; $\mathrm{CDev}=$ deviance of the child nodes; and TDev = total deviance. DevR declines from the top of the tree to the bottom. Variables that are more influential are found higher in the tree. Conventionally, the vertical distance between a node and its two immediate child nodes is representative of the amount of deviance explained in tree diagrams. For these analyses, we examined the residual deviance at individual nodes as a percentage of the total deviance of the sample to determine which variables were the most strongly influential.

Relative abundance (RA) of species following harvest was modeled using multivariate recursive partitioning (De'ath, 2002). Species dominance was modeled separately for each species group using univariate regression trees (Breiman, 1984; De'ath \& Fabricius, 2000; Venables \& Ripley, 2002). Recursive partitioning via regres- 
sion trees is a robust exploratory statistical technique (Venebles \& Ripley, 2002) and has been applied to similar vegetation analyses (e.g., Larsen \& Speckman, 2004). The technique was applied here because of the unbalanced nature of the opportunistic sample and the inherent pseudoreplication existing as a result of plots within sites (and hence, treatments).

\section{Results}

\subsection{Relative Abundance}

Sugar maple had, on average, the highest overall RA of all regenerating species in the study, and ODS regeneration was the least abundant (Table 2). Yellow birch regeneration had lower average RA than SM and the TOL group, but similar to BE, BF, and RM. Harvests creating small canopy openings (i.e., SC and SS) encouraged relative abundant regeneration of SM and the TOL group, whereas medium opening sizes had relatively more $\mathrm{RM}$ and BE regeneration (Table 2). The ITOL group and BF regeneration had higher RA in larger ( $>2 \mathrm{ha}$ ) harvest openings (i.e., RC and CC); however, BF was present in almost all opening sizes at similar RAs. Harvests creating larger openings (i.e., RC and CC) had lower BE relative abundances. Both SC and CC had lower YB relative abundances.

Sugar maple and BE regeneration RA was related to their presence in the residual overstory (Table 3). Sugar maple regeneration had high RA across all study sites, but its RA was approximately double, and with less vari-

Table 2. Relative abundance (RA, percent) of species groups by harvest treatments, ordered from smallest to largest opening (left to right), Standard errors in parentheses.

\begin{tabular}{|c|c|c|c|c|c|c|}
\hline \multirow{2}{*}{ Species Group $^{1}$} & \multicolumn{5}{|c|}{ Treatments $^{2}$} & \multirow{2}{*}{$\begin{array}{l}\text { Overall Relative } \\
\text { Abundance }\end{array}$} \\
\hline & SC & SS & PA & $\mathrm{RC}$ & CC & \\
\hline SM & $37(3.2)$ & $34(3.5)$ & $16(3.5)$ & $19(6.2)$ & $24(4.6)$ & $30(1.8)$ \\
\hline YB & $8(1.6)$ & $15(2.4)$ & $11(2.1)$ & $16(5.4)$ & $8(2.1)$ & $11(1.0)$ \\
\hline ODS & $1(0.3)$ & $1(0.1)$ & $5(1.7)$ & $0(0.1)$ & $2(0.8)$ & $2(0.4)$ \\
\hline $\mathrm{BE}$ & $16(2.4)$ & $2(0.7)$ & $21(3.1)$ & 11 (5.9) & $1(0.3)$ & $11(1.2)$ \\
\hline $\mathrm{BF}$ & $10(1.9)$ & $6(1.4)$ & $8(2.2)$ & $0(0.3)$ & 17 (4.5) & $9(1.1)$ \\
\hline $\mathrm{RM}$ & $4(1.2)$ & 7 (1.5) & $20(3.0)$ & $15(6.2)$ & $14(2.4)$ & $9(1.0)$ \\
\hline ITOL & $3(1.1)$ & $4(1.5)$ & $4(1.5)$ & 17 (5.9) & $20(3.7)$ & $6(0.9)$ \\
\hline TOL & $21(2.3)$ & 31 (3.3) & $15(2.1)$ & 22 (7.6) & $14(3.4)$ & $22(1.4)$ \\
\hline
\end{tabular}

${ }^{1} \mathrm{SM}=$ sugar maple, $\mathrm{YB}=$ yellow birch, $\mathrm{ODS}=$ other desirable species, $\mathrm{BE}=$ American beech, $\mathrm{BF}=$ balsam fir, $\mathrm{RM}=$ red maple, $\mathrm{ITOL}=$ other shade-intolerant competitors, TOL = other shade-tolerant competitors; ${ }^{2} \mathrm{SC}=$ Single-tree selection, $\mathrm{SS}=$ strip selection, $\mathrm{PA}=$ circular patch cuts; RC = seed-tree/shelterwood, $\mathrm{CC}=$ clearcut.

Table 3. Average relative abundance of regeneration ${ }^{1}$ (standard error in parentheses) by presence or absence of conspecific live stems and snags in the residual overstory ${ }^{2}$.

\begin{tabular}{ccccc}
\hline \multirow{2}{*}{ Species Group $^{3}$} & \multicolumn{2}{c}{ Live Trees $^{2}$} & \multicolumn{2}{c}{ Snags } \\
\cline { 2 - 4 } & Present & Absent & Present & Absent \\
\hline SM & $39(2.7)$ & $22(3.5)$ & $32(7.3)$ & $33(2.3)$ \\
YB & $12(1.7)$ & $9(1.9)$ & $11(3.9)$ & $11(1.3)$ \\
BE & $28(4.8)$ & $8(1.3)$ & $36(5.2)$ & $6(1.1)$ \\
BF & $10(2.9)$ & $8(1.3)$ & $7(3.7)$ & $9(1.3)$ \\
RM & $5(1.2)$ & $5(1.3)$ & $7(2.1)$ & $5(1.0)$ \\
ITOL & $9(4.3)$ & $3(0.8)$ & $0(0.0)$ & $3(0.8)$ \\
\hline
\end{tabular}

${ }^{1}$ ODS and TOL species groups excluded; plots with these species present in the overstory were uncommon in the data set; ${ }^{2} \mathrm{Applies}$ only to SC and SS treatments, and edge plots of PA treatments; ${ }^{3} \mathrm{SM}=$ sugar maple, $\mathrm{YB}=$ yellow birch, ODS = other desirable species, $\mathrm{BE}=\mathrm{American}$ beech, $\mathrm{BF}=$ balsam fir, RM = red maple, ITOL = other shade-intolerant competitors, TOL = other shade-tolerant competitors. 
ation, in areas with residual SM present in the overstory. Areas with residual overstory BE stems and snags had $\mathrm{BE}$ regeneration RA of roughly 3.5 and 6 times, respectively, that of areas where residual overstory BE was absent. Relative abundance of YB, BF, and RM regeneration varied little with or without conspecific species present in the residual overstory (Table 3).

Average RA of YB was lowest in the Northern Upland (NU) region, and highest in the Highlands and Eastern Lowlands ecoregions (Table 4). Beech regeneration had the highest RA in the Eastern Lowlands ecoregion, the ecoregion with the warmest average climate, and its RA was lowest in the Highlands, the ecoregion with the coolest average climate. Sugar maple regeneration RA was greatest in the Highlands, and it was lowest in the Eastern Lowlands. Relative abundance of RM regeneration was also highest in the Eastern Lowlands.

Sugar maple (SM) consistently had the highest RA at all TSH periods except in the 31+ year TSH period where the tolerant competitors (TOL) had a higher, although not significantly different ( $p>.05$ ), RA (Figure 2(a)). Beech had the greatest RA in the 16 - 30 year TSH period. Balsam fir and YB had moderate RA levels at all TSH periods, with both species showing a general trend of increasing RA over time. Red maple (RM) had the highest RA in the 0 - 15 year TSH period and declined with increasing TSH (Figure 2(a)).

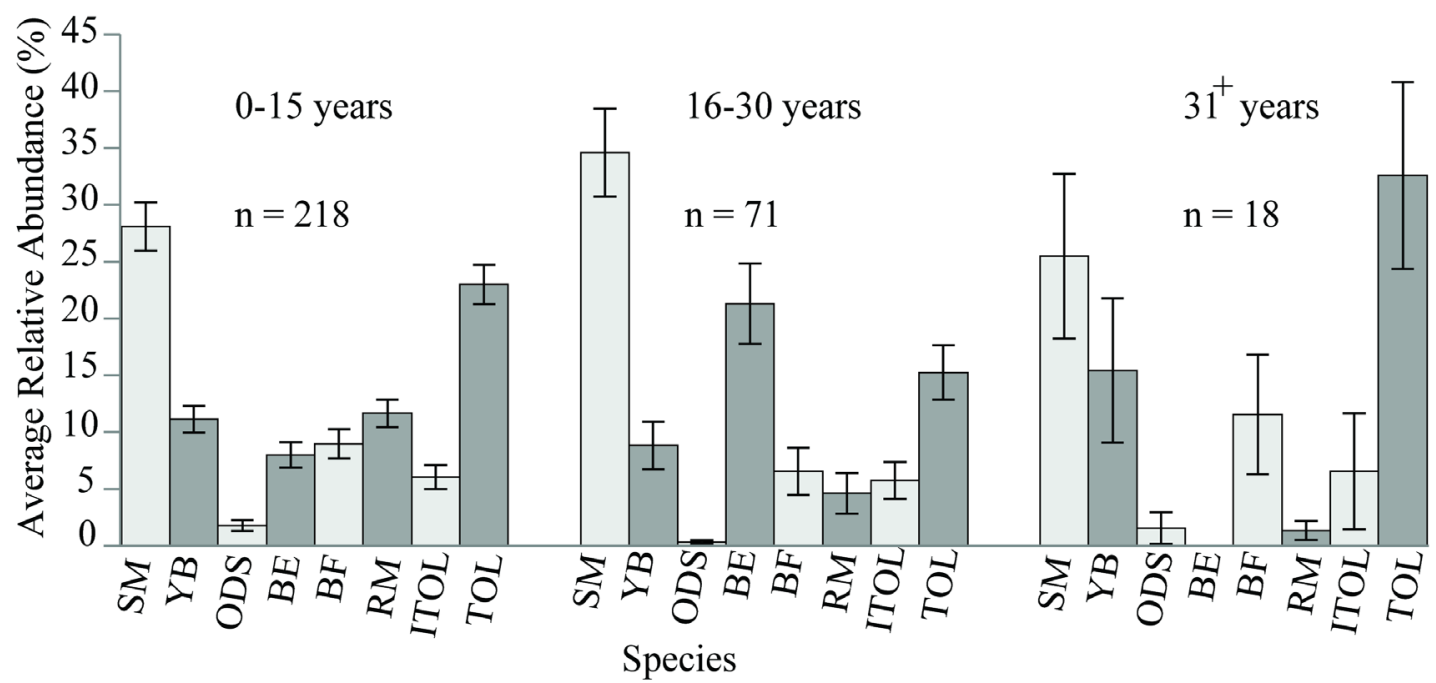

(a)

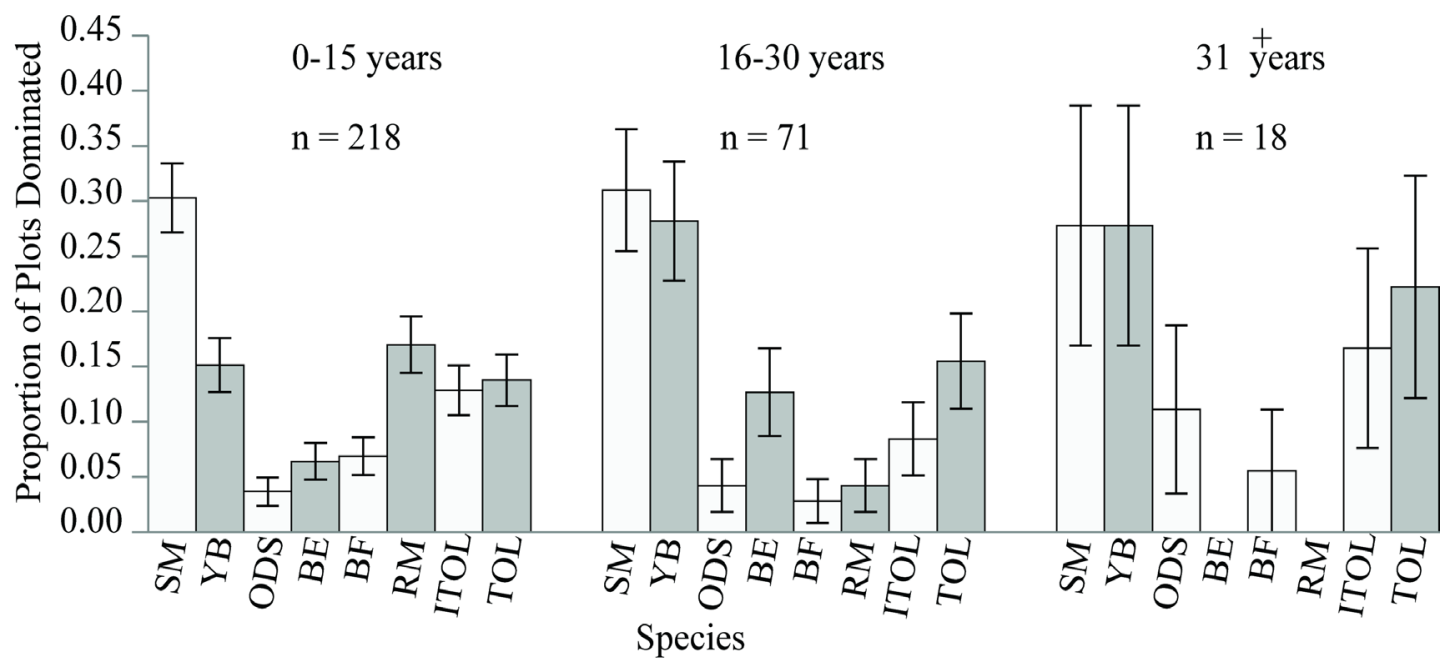

(b)

Figure 2. Species regeneration dynamics by time since harvest: (a) Relative abundance; (b) Species dominance. SM = sugar maple, $\mathrm{YB}=$ yellow birch, ODS = other desirable species, $\mathrm{BE}=$ American beech, $\mathrm{BF}=$ balsam fir, $\mathrm{RM}=$ red maple, $\mathrm{ITOL}=$ other shade-intolerant competitors, TOL $=$ other shade-tolerant competitors. 
Table 4. Average relative abundance (RA, percent) of species by ecoregion, ordered by increasing average annual growing degree days (left to right). Standard errors are in parentheses.

\begin{tabular}{|c|c|c|c|c|}
\hline \multirow{2}{*}{ Species Group ${ }^{1}$} & \multicolumn{4}{|c|}{ Region } \\
\hline & Highlands & Northern Uplands & Central Uplands & Eastern Lowlands \\
\hline SM & $42(3.9)$ & $30(2.8)$ & $25(3.9)$ & $20(4.0)$ \\
\hline YB & $17(2.4)$ & $6(1.3)$ & $10(2.0)$ & $15(2.8)$ \\
\hline ODS & $1(0.1)$ & $1(0.2)$ & $1(0.5)$ & $5(1.8)$ \\
\hline $\mathrm{BE}$ & $1(0.6)$ & $13(2.2)$ & $12(2.7)$ & $16(2.9)$ \\
\hline $\mathrm{BF}$ & $4(1.3)$ & $11(2.0)$ & $10(2.6)$ & $8(2.4)$ \\
\hline $\mathrm{RM}$ & $11(2.2)$ & $3(0.8)$ & $13(2.7)$ & $17(2.8)$ \\
\hline ITOL & $8(2.1)$ & $4(1.4)$ & $12(2.4)$ & $1(0.4)$ \\
\hline TOL & $16(2.6)$ & $29(2.7)$ & $17(2.8)$ & $18(2.3)$ \\
\hline
\end{tabular}

${ }^{1} \mathrm{SM}=$ sugar maple, $\mathrm{YB}=$ yellow birch, $\mathrm{ODS}=$ other desirable species, $\mathrm{BE}=$ American beech, $\mathrm{BF}=$ balsam fir, $\mathrm{RM}=$ red $\mathrm{maple}, \mathrm{ITOL}=\mathrm{other}$ shade-intolerant competitors, TOL = other shade-tolerant competitors.

The multivariate regression tree for species RA accounted for approximately $18 \%$ of total deviance (Figure 3). Presence of SM in the residual overstory was the most influential factor determining regeneration composition following harvest. Sugar maple regeneration was a major component of most assemblages delineated by the regression tree; however, SM regeneration had greater RA in areas with residual overstory SM. Areas with residual BE snags had higher relative abundance of BE regeneration than those where they were absent; however, this effect was reduced after 15 years following harvest treatment (Figure 2 \& Figure 3) even though BE had highest RA in the 16 - 30 year TSH class. Effects of harvesting varied, depending on the residual overstory, but PA harvests generally had greater RA of BE regeneration than the other treatments. Tolerant competitors (TOL) were a major component of all identified assemblages, and, while BF was a component, BF was more abundant on sites where SM and BE were not present in the residual overstory (Figure 3).

\subsection{Species Dominance}

Sugar maple and YB were the two most dominant regenerating species groups (Table 5). The ODS group, BE and BF were the least dominant regenerating species groups. Harvests creating small canopy openings (i.e., SS and SC) favored dominance by SM regeneration; however, SM expressed dominance in all harvest types (Table 5). Red maple was most dominant on sites with medium-sized openings (i.e., PA), but it was also commonly dominant in the largest openings (i.e., CC). Yellow birch regeneration dominated most in PA harvests, but was also found to dominate the smaller canopy openings (i.e., SC). The ITOL group's regeneration was the most dominant on RC sites. The harvest treatments with the largest opening sizes (i.e., RC and CC) tended to produce the most diversity in species dominance with a relatively even distribution of dominance across most species groups (Table 5).

Sugar maple regeneration had the greatest dominance in the cooler regions (i.e., the Highlands and Northern Uplands ecoregions), and generally decreased with increasing average regional temperature (Table 6). Red maple (RM), BE, and YB dominance generally displayed the opposite trend. Red maple dominance decreased with increasing TSH (Figure 2(b)), whereas YB, ODS, and TOL regeneration dominance increased with TSH. Sugar maple dominance was more or less constant over the range of TSH.

The univariate regression trees for dominance of regeneration explained 5\% - 15\% of the total deviance in dominance across the various species groups (Table 7). Regression trees for BF, RM, and ODS regeneration were not produced due to the infrequent dominance of these species. Beech regeneration dominance had a positive relationship with increasing total residual live basal area and with total standing (i.e., live and dead) basal area (Table 7). The ITOL group had a negative correlation with increasing total standing basal area. Dominance of the TOL group's regeneration was positively related to the presence of BF snags in the residual overstory. Beech regeneration dominance was strongly positively related to the presence of BE snags in the residual over- 


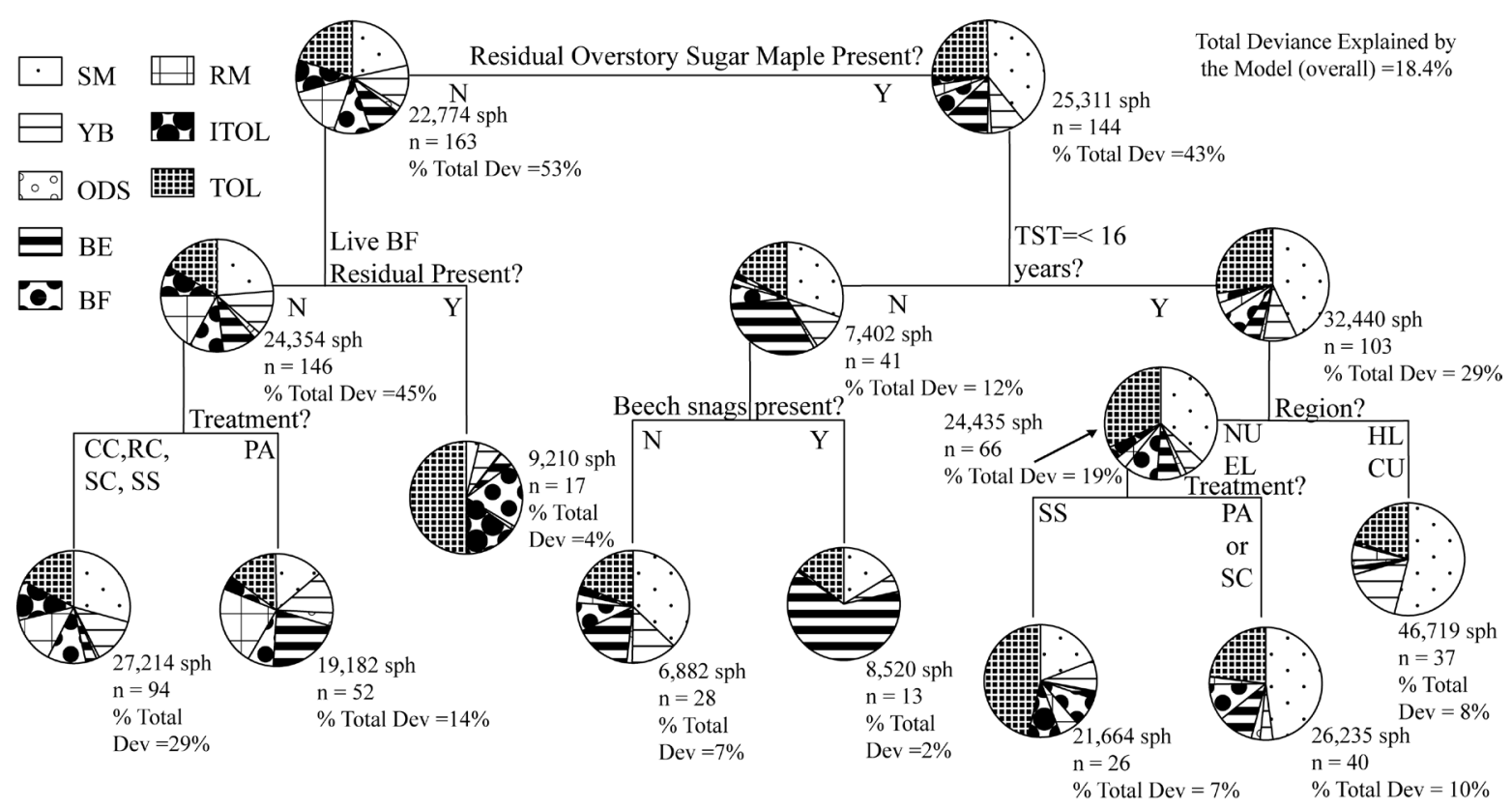

Figure 3. Multivariate regression tree of relative abundance (RA) by species group. Labels at each node show variables and values where splits occur. Pie labels indicate average total density of all species in stems per ha (sph), the number of observations (n), the residual deviance at the node as a percentage of the total deviance of the entire sample (\% Total Dev), and the total deviance explained by the model as a whole (top right). SM = sugar maple, YB = yellow birch, ODS = other desirable species, $\mathrm{BE}=$ American beech, $\mathrm{BF}=$ balsam fir, $\mathrm{RM}=$ red maple, $\mathrm{ITOL}=$ other shade-intolerant competitors, $\mathrm{TOL}=$ other shade-tolerant competitors, TSH = time since harvest, $\mathrm{CC}=$ clearcut, $\mathrm{RC}=$ seed-tree/shelterwood, $\mathrm{SC}=\mathrm{Single}$-tree selection, SS = strip selection.

Table 5. Species dominance (proportion of plots with that species as the tallest regenerating tree) by harvest treatment. Harvest treatments are ordered by increasing opening size (left to right). Standard errors (in parentheses) were calculated using the binomial distribution.

\begin{tabular}{|c|c|c|c|c|c|c|}
\hline \multirow{2}{*}{$\begin{array}{l}\text { Species } \\
\text { Group }^{1}\end{array}$} & \multicolumn{5}{|c|}{ Treatments $^{2}$} & \multirow{2}{*}{$\begin{array}{c}\text { Overall } \\
\text { Dominance }\end{array}$} \\
\hline & SC & SS & $\mathrm{PA}$ & $\mathrm{RC}$ & CC & \\
\hline SM & $34(4.4)$ & 38 (5.3) & $16(4.7)$ & 17 (10.8) & $26(7.1)$ & $29(2.6)$ \\
\hline YB & $22(3.8)$ & $12(3.5)$ & $25(5.6)$ & 17 (10.8) & $11(5.2)$ & $19(2.2)$ \\
\hline ODS & $1(0.9)$ & $2(1.4)$ & $2(1.7)$ & $0(-)$ & $7(4.1)$ & $4(1.2)$ \\
\hline $\mathrm{BE}$ & $11(2.9)$ & $2(1.7)$ & $12(4.2)$ & $8(8.0)$ & $0(-)$ & $6(1.5)$ \\
\hline $\mathrm{BF}$ & $8(2.5)$ & $1(1.2)$ & $0(-)$ & $0(-)$ & $20(6.5)$ & $5(1.3)$ \\
\hline $\mathrm{RM}$ & $3(1.7)$ & $10(3.2)$ & $30(5.9)$ & 17 (10.8) & $18(6.2)$ & $12(1.9)$ \\
\hline ITOL & $5(2.1)$ & 12 (3.6) & $8(3.6)$ & 25 (12.5) & $15(5.8)$ & $11(1.0)$ \\
\hline TOL & $16(3.4)$ & $23(4.6)$ & $7(3.3)$ & $16(10.5)$ & $0(-)$ & $14(2.0)$ \\
\hline
\end{tabular}

${ }^{1} \mathrm{SM}=$ sugar maple, $\mathrm{YB}=$ yellow birch, $\mathrm{ODS}=$ other desirable species, $\mathrm{BE}=$ American beech, $\mathrm{BF}=$ balsam fir, RM = red maple, ITOL = other shade-intolerant competitors, TOL $=$ other shade-tolerant competitors. ${ }^{2} \mathrm{SC}=$ Single-tree selection, $\mathrm{SS}=$ strip selection, $\mathrm{PA}=$ circular patch cuts; $\mathrm{RC}$ = seed-tree/shelterwood, CC $=$ clearcut.

story. Sugar maple residual basal area had a positive correlation with SM regeneration dominance. Ecoregion was a commonly significant variable among the SM, YB, and ITOL dominance models, and it was the prime splitting variable for SM and ITOL (Table 7). Yellow birch regeneration dominance was the only species group that increased dominance with increasing TSH. 
Table 6. Species dominance (proportion of plots with that species as the tallest regenerating tree) by ecoregion. Ecoregions are ordered by increasing annual growing degree days (left to right). Standard errors (in parentheses) were calculated using the binomial distribution.

\begin{tabular}{ccccc}
\hline \multirow{2}{*}{ Species $^{1}$} & \multicolumn{3}{c}{ Ecoregion } \\
\cline { 2 - 4 } SM & Highlands & Northern Uplands & Central Uplands & Eastern Lowlands \\
YB & $47(5.9)$ & $32(4.3)$ & $18(5.2)$ & $13(4.5)$ \\
ODS & $14(4.2)$ & $12(3.1)$ & $23(5.7)$ & $31(6.3)$ \\
BE & $5(2.7)$ & $4(1.8)$ & $4(2.9)$ & $2(1.8)$ \\
BF & $3(1.9)$ & $7(2.4)$ & $6(3.4)$ & $14(4.8)$ \\
RM & $4(2.3)$ & $8(2.6)$ & $5(3.1)$ & $0(-)$ \\
ITOL & $11(3.9)$ & $4(1.8)$ & $16(5.0)$ & $29(6.2)$ \\
TOL & $7(3.2)$ & $11(3.0)$ & $24(5.8)$ & $2(1.8)$ \\
\hline
\end{tabular}

${ }^{1} \mathrm{SM}=$ sugar maple, $\mathrm{YB}=$ yellow birch, $\mathrm{ODS}=$ other desirable species, $\mathrm{BE}=$ American beech, $\mathrm{BF}=$ balsam fir, $\mathrm{RM}=$ red maple, ITOL $=$ other shade-intolerant competitors, TOL = other shade-tolerant competitors

Table 7. Influence ${ }^{1}$ of explanatory variables on dominance of species groups based on univariate recursive partitioning (univariate regression trees).

\begin{tabular}{|c|c|c|c|c|c|}
\hline \multirow{2}{*}{ Explanatory Variable } & \multicolumn{5}{|c|}{ Species Group ${ }^{2}$} \\
\hline & SM & YB & $\mathrm{BE}$ & ITOL & TOL \\
\hline \multicolumn{6}{|l|}{ Residual Overstory Basal Area } \\
\hline SM Live & $\uparrow$ & & & & \\
\hline Total Live & $\uparrow$ & & $\uparrow$ & & \\
\hline BE Snags & & & $\uparrow^{*}$ & & \\
\hline BF Snags & & & & & $\uparrow^{*}$ \\
\hline Total Standing (Live + Snags) & $\downarrow$ & & $\uparrow$ & $\downarrow$ & \\
\hline \multicolumn{6}{|c|}{ Residual Overstory Species Composition (\%) } \\
\hline $\mathrm{BE}$ & & $\downarrow$ & & & \\
\hline RS & & $\uparrow$ & & & \\
\hline \multicolumn{6}{|l|}{ Other Abiotic Factors } \\
\hline $\mathrm{TSH}^{3}$ & & $\uparrow^{*}$ & & & \\
\hline Ecoregion & $\leftrightarrow^{*}$ & $\leftrightarrow$ & & $\leftrightarrow{ }^{*}$ & \\
\hline Treatment & & & & $\leftrightarrow$ & \\
\hline Deviance Explained (\%) & 15 & 11 & 13 & 13 & 5 \\
\hline
\end{tabular}

${ }^{1}$ Vertical arrows indicate a variable has a negative or positive effect on dominance when increased; horizontal arrows denote effects of variables that do not show clear increases or decreases in dominance, but represent splits with significant reductions in deviance; arrow size indicates average percentage of node deviance reduced (i.e., $\uparrow \geq 50 \%, 20 \% \leq \uparrow<50 \%$, and $0 \%<\uparrow \leq 19 \%$ ), irrespective of changes in sample size. Asterisks indicate the prime splitting variable. ${ }^{2} \mathrm{SM}=$ sugar maple, $\mathrm{YB}=$ yellow birch, $\mathrm{BE}=$ American beech, $\mathrm{RS}=$ red spruce, ITOL = other shade-intolerant competitors, $\mathrm{TOL}=$ other shade-tolerant competitors; ${ }^{3} \mathrm{TSH}=$ time since harvest treatment (years).

\section{Discussion}

Our study represents one of the first attempts to formally explore factors controlling natural regeneration following variable harvesting treatments in the Acadian Forest, with its unique mixture of northern hardwoods and boreal forest species. Results from our study indicate that, similar to those of Chapin et al. (1994), no single mechanism controls the regeneration dynamics of Acadian tree species following harvest, but rather regeneration is highly influenced by: 1) harvest type, which varies largely by canopy opening size, demonstrating the 
importance of light availability on regeneration (Huston \& Smith, 1987; Matias et al., 2011); 2) residual overstory composition following harvest, which supports the direct-regeneration hypothesis that post-disturbance tree species regeneration (including advanced regeneration) is highly determined by pre-disturbance species composition (Ilisson \& Chen, 2009); and 3) climate and soil conditions, which vary according to ecoregion, and have strong control over the relative competitiveness of tree species (Kreyling et al., 2011; Swenson et al., 2012). Further, by observing and measuring regeneration responses over different times since disturbances, our results clearly show a shift in early regeneration composition from shade-intolerant, early succession species to increasing dominance by later-succession species, conforming to well-known patterns of early forest succession (Oliver, 1981; Swanson et al., 2011; Veblen, 1992).

Sugar maple, one of the most desirable tolerant hardwood species in the Acadian Forest Region, responded well, in terms of both Relative Abundance (RA) and dominance, to a variety of overstory openings from single tree selection to clearcutting (Table 2 \& Table 5). The main factor influencing SM RA and dominance was the presence of SM in the residual overstory (Table 3 \& Table 7; Figure 3). Although SM had the greatest RA and dominance in the harvest treatments creating the smallest openings (Table 2 \& Table 5), it was found in relatively high levels across the range of harvest levels studied here. The reduction of SM RA with increasing opening size was primarily a function of an increase in the abundance of other competing species (Table 2; Figure 3). Arseneault et al. (2011) observed similar results following the first 10 years after implementing an irregular shelterwood system in an Acadian hardwood forest in Maine.

The ecoregional differences observed for SM are also of interest (Table 4 \& Table 6). The differences between regions appear to align along a gradient of growing season length with relative abundance (Table 4) and dominance (Table 6) of SM regeneration increasing under shorter growing seasons. This most likely reflects SM's greater northern affinity, relative to BE and RM in this study (Anderson et al., 1999), explaining its greater RA in cooler regions where these other species are less competitive. Ecoregional differences for other species groups were observed; however, these differences did not correspond to the implied climate gradients associated with the ecoregions sampled in this study. The differences for these groups may be related to other site factors coupled with the ecoregion classification, including soil properties. For instance, the Highlands and Central Uplands regions generally have well-drained soils, whereas the Eastern Lowlands region has a much higher water table and flatter terrain, resulting in poorer drainage conditions (Zelazny et al., 2003). Kobe et al. (1995) found that SM survivorship was negatively affected by reduced site quality, which may be one reason why the Eastern Lowlands ecoregion had much lower SM RA.

Time since harvest was another factor influencing species relative abundance and dominance. Red maple regeneration had higher RA and dominance in the more recent harvests and declined with increasing time since harvest. Hibbs (1983) reported similar trends for large-scale disturbance sites in central New England. In that study, RM dominated in the early years following disturbance, but was generally overtopped within 40 years. This is likely related to vigorous stump sprouting followed by rapid self-thinning of dense sprouts as they are overtopped by other species (Prager \& Goldsmith, 1978). The increased presence of RM in much of northeastern North America has been attributed to contemporary forest management activities (Abrams, 1998; Boucher et al., 2006; Fei \& Steiner, 2007). The results here suggest that this phenomenon may be more a function of stage of stand development; however, silvicultural treatments such as precommercial thinning may inadvertently favor RM if the taller sprouts are chosen as crop trees rather than other more valuable species. Red maple saplings have been shown to respond well to crop tree release (Lamson \& Smith, 1991; Strong, 2005; Strong et al., 2006).

Sugar maple consistently had the greatest RA and dominance across the range of time since harvest observed in this study (Figure 2). The silvics of SM (e.g., MacDonald \& Powell (1983) and Marks \& Gardescu (1998)) suggest that regeneration is primarily through advanced regeneration. Advanced regeneration has been perpetuating SM throughout eastern North America, even following treatments where few overstory residuals were left (Leak \& Wilson Jr., 1958; Jones et al., 1989; Leak, 2005). Therefore, it would seem plausible that advanced regeneration is playing a major role in enabling SM regeneration to establish high levels of RA and maintain dominance over time. The tolerant hardwood competitor species group had RA and dominance similar to SM in the longest time since harvest class (Figure 2). Given the absence of these species in the residual overstory and their generally shorter heights, it is more likely that the TOL individuals will exert a greater impact on the next cohort of advanced regeneration than be a serious competitor with SM and YB in the current cohort.

The dynamics of BE in northern New England and the Acadian Forest has been greatly impacted by the beech 
bark disease (Farrar \& Ostrofsky, 2006; Leak, 2006b). Beech is generally a prolific root sprouter, particularly diseased BE, and, in many cases, forms dense clumps of pure BE (Farrar \& Ostrofsky, 2006). Because these root sprouts are from susceptible genotypes, the cycle of death, sprouting, reinfestation, death, and resprouting is frequently observed. This cycle may explain the trend observed in this study, where BE achieved its greatest RA and dominance in the 16 - 30 years following time since harvest and was virtually absent in the $>30$ year class. Beech was not observed to be an aggressive competitor in this study as has been observed elsewhere in northeastern North America (Farrar \& Ostrofsky, 2006; Houston, 1980; Le Guerrier et al., 2003; Leak, 2006b; Ostrofsky \& Houston, 1988).

Yellow birch was the only species that showed a consistent increase in RA and dominance over time since harvest (Figure 2). Although moderately abundant in most treatments, YB was the most abundant and dominant in the patch cut treatments and, to a slightly lesser degree the selection cut treatments. Yellow birch primarily regenerates from seed and has the best regeneration success when the forest floor is heavily disturbed, exposing mineral soil (Elie et al., 2009; Gilbert, 1960). The results observed here are consistent for a species that is intermediate in shade tolerance and would have regenerated following disturbance rather than a species that arises from advanced regeneration.

The period immediately following a disturbance, natural or human-caused, is critical to the establishment of a new cohort of trees. Our results seem to indicate that a variety of harvest treatments can successfully regenerate tolerant species, but a number of other factors must be taken into account including the presence of the species in the overstory, presence of other competing species, and time since harvest. It can be very difficult to assess success of natural regeneration during the first decade following treatment (Arseneault et al., 2011; Morrissey et al., 2010). A variety of species can regenerate following a disturbance of any size (Arseneault et al., 2011). Silvicultural monitoring programs that target specific points in time may result in incorrect decisions regarding silviculture success or failure (Kershaw Jr. \& VanDamme, 2012), especially if the monitoring techniques are adapted from plantation monitoring programs. Assessment of success is further complicated by shifting demands for forest products, shifting management responsibilities, and rolling management planning horizons that result in inconsistent silvicultural objectives and approaches over time. Although the retrospective approach adapted in this study provided a means for a timely initial assessment of partial harvesting in the Acadian Forests of New Brunswick, more controlled experimentation, similar to the Acadian Forest Ecosystem Research Project in Maine (Arseneault et al., 2011), and many others elsewhere, is needed in the Acadian Forest in New Brunswick.

\section{Acknowledgements}

We would like to thank Jasen Golding of the University of New Brunswick and Adam Dick, New Brunswick Department of Natural Resources, for helping locate suitable field sites. Gareth Cockwell, Mike Hutchinson, Mike Szuter, Trent MacCauley, as well as staff of the Northern Hardwoods Research Institute (NHRI) and CFDS Enterprises Ltd. must be acknowledged for their tireless assistance in the field. Historical stand information was provided with assistance from Jean-Louis Laplante of NHRI, as well as Bernice Johnstone, Todd Beach, and Kevin Comeau of the New Brunswick Department of Natural Resources. This work was supported in part by the Northern Hardwoods Research Institute of New Brunswick. Funding for this project was provided in part by the Natural Sciences and Engineering Research Council of Canada, the New Brunswick Department of Natural Resources, and the Northern Hardwoods Research Institute.

\section{References}

Abrams, M. D. (1998). The Red Maple Paradox. BioScience, 48, 355-364. http://dx.doi.org/10.2307/1313374

Anderson, H., Chambers, B., Rice, J., Merchant, B., \& Wright, K. (1999). Section 4.0: Silvics, In: Silvicultural Guide for the Tolerant Hardwood Forest in Ontario (p. 35.). Toronto: Queen's Printer for Ontario, Ontario Ministry of Natural Resources.

Archambault, L., Delisle, C., \& Larocque, G. R. (2009). Forest Regeneration 50 Years following Partial Cutting in Mixedwood Ecosystems of Southern Quebec, Canada. Forest Ecology and Management, 257, 703-711. http://dx.doi.org/10.1016/j.foreco.2008.09.056

Arseneault, J. E., Saunders, M. R., Seymour, R. S., \& Wagner, R. G. (2011). First Decadal Response to Treatment in a Disturbance-Based Silviculture Experiment in Maine. Forest Ecology and Management, 262, 404-412.

http://dx.doi.org/10.1016/j.foreco.2011.04.006 
Bataineh, M., Kenefic, L. S., Weiskittel, A. R., Wagner, R. G., \& Brissette, J. C. (2013). Influence of Partial Harvesting and Site Factors on the Abundance and Composition of Natural Regeneration in the Acadian Forest of Maine, USA. Forest Ecology and Management, 306, 96-106. http://dx.doi.org/10.1016/j.foreco.2013.06.016

Betts, M., \& Loo, J. (2002). A Comparison of Pre-European Settlement Forest Characterization Methodologies. The Forestry Chronicle, 78, 422-432. http://dx.doi.org/10.5558/tfc78422-3

Bose, A. K., Harvey, B. D., Brais, S., Beaudet, M., \& Leduc, A. (2014). Constraints to Partial Cutting in the Boreal Forest of Canada in the Context of Natural Disturbance Based Management: A Review. Forestry, 87, 11-28. http://dx.doi.org/10.1093/forestry/cpt047

Boucher, Y., Arseneault, D., \& Sirois, L. (2006). Logging-Induced Change (1930-2002) of a Preindustrial Landscape at the Northern Range Limit of Northern Hardwoods, Eastern Canada. Canadian Journal of Forest Research, 36, 505-517. http://dx.doi.org/10.1139/x05-252

Brais, S., Work, T. T., Robert, É., O’Conner, C. D., Strukelj, M., Bose, A. K., Celentano, D., Harvey, B. D. (2013). Ecosystem Responses to Partial Harvesting in Eastern Boreal Mixedwood Stands. Forests, 4, 364-385.

http://dx.doi.org/10.3390/f4020364

Breiman, L. (1984). Classification and Regression Trees. Belmont, CA: Wadsworth International Group.

Carlson, D. W., \& Groot, A. (1997). Microclimate of Clearcut, Forest Interior, and Small Openings in Trembling Aspen Forest. Agricultural and Forest Meteorology, 87, 313-329. http://dx.doi.org/10.1016/S0168-1923(95)02305-4

Cattelino, P., Noble, I., Slatyer, R., \& Kessell, S. (1979). Predicting the Multiple Pathways of Plant Succession. Environmental Management, 3, 41-50. http://dx.doi.org/10.1007/BF01867067

Chapin, F. S., Walker, L. R., Fastie, C. L., Sharman, L. C. (1994). Mechanisms of Primary Succession Following Deglaciation at Glacier Bay, Alaska. Ecological Monographs, 64, 149-175. http://dx.doi.org/10.2307/2937039

Christensen, N. L., Bartuska, A. M., Brown, J. H., Carpenter, S., D’Antonio, C., Francis, R. et al. (1996). The Report of the Ecological Society of America Committee on the Scientific Basis for Ecosystem Management. Ecological Applications, 6, 665-691. http://dx.doi.org/10.2307/2269460

Clements, F. E. (1916). Plant Succession. Washington DC: Carnegie Institute.

Colpitts, M. C. (1995). Forest Soils of New Brunswick. New Brunswick: Department of Natural Resources and Energy, Timber Management Branch Fredericton.

Dale, M. E., Smith, H. C., \& Pearcy, J. N. (1995). Size of Clearcut Opening Affects Species Composition, Growth Rate, and Stand Characteristics. Res. Pap. NE-698, USDA, Forest Service, Northeastern Forest Experiment Station.

De'ath, G. (2002). Multivariate Regression Trees: A New Technique for Modeling Species-Environment Relationships. Ecology, 83, 1105-1117.

De'ath, G., \& Fabricius, K. E. (2000). Classification and Regression Trees: A Powerful yet Simple Technique for Ecological Data Analysis. Ecology, 81, 3178-3192. http://dx.doi.org/10.1890/0012-9658(2000)081[3178:CARTAP]2.0.CO;2

Drury, W., \& Nisbet, I. (1973). Succession. Journal of the Arnold Arboretum, 54, 331-368.

Elie, J.-G., Ruel, J.-C., \& Lussier, J.-M. (2009). Effect of Browsing, Seedbed, and Competition on the Development of Yellow Birch Seedlings in High-Graded Stands. Northern Journal of Applied Forestry, 26, 99-105.

Engelman, H. M., \& Nyland, R. D. (2006). Interference to Hardwood Regeneration in Northeastern North America: Assessing and Countering Ferns in Northern Hardwood Forests. Northern Journal of Applied Forestry, 23, 166-175.

Environment Canada (2013). Canadian Climate Normals. http://climate.weather.gc.ca/climate_normals/index_e.html

Farrar, A., \& Ostrofsky, W. D. (2006). Dynamics of American Beech Regeneration 10 Years Following Harvesting in a Beech Bark Disease-Affected Stand in Maine. Northern Journal of Applied Forestry, 23, 192-196.

Fei, S., \& Steiner, K. C. (2007). Evidence for Increasing Red Maple Abundance in the Eastern United States. Forest Science, 53, $473-477$.

Floyd, D. W., Ritchie, R., \& Rotherham, T. (2012). New Approaches for Private Woodlots: Reframing the Forest Policy Debate. Private Forest Task Force Report, Fredericton, New Brunswick: Government of New Brunswick.

Gilbert, A. M. (1960). Silvical Characteristics of Yellow Birch (Betula alleghaniensis). Station Pap. SP-NE-134, USDA, Forest Service, Northeastern Forest Experiment Station.

Gilbert, A. M., \& Jensen, V. S. (1958). A Management Guide for Northern Hardwoods in New England. Station Pap. SP-NE-112, USDA, Forest Service, Northeastern Forest Experiment Station.

Gould, P. J., Steiner, K. C., Finley, J. C., \& McDill, M. E. (2005). Developmental Pathways Following the Harvest of Oak-Dominated Stands. Forest Science, 51, 76-90.

Government of Canada (1962). The Climate of Canada. Toronto: Meteorological Division, Air Services Branch, Department of Transport. 
Greene, D. F., Zasada, J. C., Sirois, L., Kneeshaw, D., Morin, H., Charron, I., \& Simard, M. J. (1999). A Review of the Regeneration Dynamics of North American Boreal Forest Tree Species. Canadian Journal of Forest Research, 29, 824-839. http://dx.doi.org/10.1139/x98-112

Harvey, B. D., Leduc, A., Gauthier, S., \& Bergeron, Y. (2002). Stand-Landscape Integration in Natural Disturbance-Based Management of the Southern Boreal Forest. Forest Ecology and Management, 155, 369-385. http://dx.doi.org/10.1016/S0378-1127(01)00573-4

Hibbs, D. E. (1983). Forty Years of Forest Succession in Central New England. Ecology, 64, 1394-1401. http://dx.doi.org/10.2307/1937493

Houston, D. (1980). Beech Bark Disease: What We Do and Do Not Know. Annals of Forest Science, 37, $269-274$. http://dx.doi.org/10.1051/forest:19800401

Husch, B., Beers, T. W., \& Kershaw Jr., J. A. (2002). Forest Mensuration. Hoboken, NJ: John Wiley \& Sons.

Huston, M., \& Smith, T. (1987). Plant Succession: Life History and Competition. The American Naturalist, 130, $168-198$. http://dx.doi.org/10.1086/284704

Ilisson, T., \& Chen, H. Y. H. (2009). The Direct Regeneration Hypothesis in Northern Forests. Journal of Vegetation Science, 20, 735-744. http://dx.doi.org/10.1111/j.1654-1103.2009.01066.x

Jones, R. H., Nyland, R. D., \& Raynal, D. J. (1989). Response of American Beech Regeneration to Selection Cutting of Northern Hardwoods in New York. North. J. Appl. For. 6, 34-36.

Kershaw Jr., J. A., \& VanDamme, L. (2012). Monitoring Partial Harvests for Silvicultural Liability Purposes. Internal Report prepared for the Ontario Ministry of Natural Resources.

Kobe, R. K., Pacala, S. W., Silander Jr., J. A., \& Canham, C. D. (1995). Juvenile Tree Survivorship as a Component of Shade Tolerance. Ecological Applications, 5, 517-532. http://dx.doi.org/10.2307/1942040

Kreyling, J., Jentsch, A., \& Beierkuhnlein, C. (2011). Stochastic Trajectories of Succession Initiated by Extreme Climatic Events. Ecology Letters, 14, 758-764. http://dx.doi.org/10.1111/j.1461-0248.2011.01637.x

Kuuluvainen, T., \& Grenfell, R. (2012). Natural Disturbance Emulation in Boreal Forest Ecosystem Management-Theories, Strategies, and a Comparison with Conventional Even-Aged Management. Canadian Journal of Forest Research, 42, 1185-1203. http://dx.doi.org/10.1139/x2012-064

Lamson, N. I., \& Smith, H. C. (1991). Stand Development and Yields of Appalachian Hardwood Stands Managed with Single-Tree Selection for at Least 30 Years. Res. Pap. RP-NE-655, USDA, Forest Service, Northeastern Forest Experiment Station.

Larsen, D. R., \& Speckman, P. L. (2004). Multivariate Regression Trees for Analysis of Abundance Data. Biometrics, 60, 543-549. http://dx.doi.org/10.1111/j.0006-341X.2004.00202.x

Le Guerrier, C., Marceau, D. J., Bouchard, A., \& Brisson, J. (2003). A Modelling Approach to Assess the Long-Term Impact of Beech Bark Disease in Northern Hardwood Forest. Canadian Journal of Forest Research, 33, 2416-2425. http://dx.doi.org/10.1139/x03-170

Leak, W. B. (1996). Long-Term Structural Change in Uneven-Aged Northern Hardwoods. Forest Science, 42, 160-165.

Leak, W. B. (2005). Effects of Small Patch Cutting on Sugar Maple Regeneration in New Hampshire Northern Hardwoods. Northern Journal of Applied Forestry, 22, 68-70.

Leak, W. B. (2006a). Sixty Years of Change in the Sapling Understories of Northern Hardwood Selection Stands in New Hampshire. Northern Journal of Applied Forestry, 23, 301-303.

Leak, W. B. (2006b). Fifty-Year Impacts of the Beech Bark Disease in the Bartlett Experimental Forest, New Hampshire. Northern Journal of Applied Forestry, 23, 141-143.

Leak, W. B., \& Filip, S. M. (1977). Thirty-Eight Years of Group Selection in New England Northern Hardwoods. Journal of Forestry, 75, 641-643.

Leak, W. B., \& Wilson Jr., R. W. (1958). Regeneration after Cutting of Old-Growth Northern Hardwoods in New Hamphire. Station Pap. SP-NE-103, USDA, Forest Service, Northeastern Forest Experiment Station.

Lees, J. C. (1978). Hardwood Silviculture and Management: An Interpretive Literature Review for the Canadian Maritime Provinces. Information Rep. M-X-93, Canadian Forest Service-Atlantic Forestry Centre.

Lees, J. C. (1981). Three Generations of Red Maple Stump Sprouts. Information Rep. M-X-119, Environment Canada, Canadian Forestry Service, Maritimes Forest Research Centre.

Levin, S. A. (1992). The Problem of Pattern and Scale in Ecology: The Robert H. MacArthur Award Lecture. Ecology, 73, 1943-1967. http://dx.doi.org/10.2307/1941447 
Loftis, D. L. (1983). Regenerating Southern Appalachian Mixed Hardwood Stands with the Shelterwood Method. Southern Journal of Applied Forestry, 7, 212-217.

Logan, K. T. (1965). Growth of Tree Seedlings as Affected by Light Intensity. I. White Birch, Yellow Birch, Sugar Maple and Silver Maple. Department of Forestry Application No. 1121, Ottawa: Ministry of Forestry.

Longpre, T. W., \& Morris, D. M. (2012). Environmental Drivers of Succession in Jack Pine Stands of Boreal Ontario: An Application of Survival Analysis. Northern Journal of Applied Forestry, 29, 81-92. http://dx.doi.org/10.5849/njaf.11-016

Loo, J., \& Ives, N. (2003). The Acadian Forest: Historical Condition and Human Impacts. The Forestry Chronicle, 79, 462-474. http://dx.doi.org/10.5558/tfc79462-3

MacDonald, J. E., \& Powell, G. R. (1983). Relationships between Stump Sprouting and Parent-Tree Diameter in Sugar Maple in the 1st Year Following Clearcutting. Canadian Journal of Forest Research, 13, 390-394. http://dx.doi.org/10.1139/x83-058

Marks, P. L., \& Gardescu, S. (1998). A Case Study of Sugar Maple (Acer saccharum) as a Forest Seedling Bank Species. The Journal of the Torrey Botanical Society, 125, 287-296. http://dx.doi.org/10.2307/2997242

Marquis, D. A. (1967). Clearcutting in Northern Hardwoods: Results after 30 Years. Res. Pap. NE-85, USDA, Forest Service, Northeastern Forest Experiment Station.

Marquis, D. A. (1979). Shelterwood Cutting in Allegheny Hardwoods. Journal of Forestry, 77, 140-144.

Martin, C. W., \& Hornbeck, J. W. (1989). Revegetation after Strip Cutting and Block Clearcutting in Northern Hardwoods: A 10-Year History. Res Pap NE-625, USDA, Forest Service, Northeastern Forest Experiment Station.

Matias, L., Gomez-Aparicio, L., Zamora, R., \& Castro, J. (2011). Effects of Resource Availability on Plant Recruitment at the Community Level in a Mediterranean Mountain Ecosystem. Perspectives in Plant Ecology, Evolution and Systematics, 13, 277-285. http://dx.doi.org/10.1016/j.ppees.2011.04.005

Matonis, M. S., Walters, M. B., \& Millington, J. D. A. (2011). Gap-, Stand-, and Landscape-Scale Factors Contribute to Poor Sugar Maple Regeneration after Timber Harvest. Forest Ecology and Management, 262, 286-298. http://dx.doi.org/10.1016/j.foreco.2011.03.034

McGill, B. J. (2010). Matters of Scale. Science, 328, 575-576. http://dx.doi.org/10.1126/science.1188528

Morin, R. S., Liebhold, A. M., Tobin, P. C., Gottschalk, K. W., \& Luzader, E. (2007). Spread of Beech Bark Disease in the Eastern United States and Its Relationship to Regional Forest Composition. Canadian Journal of Forest Research, 37, 726-736. http://dx.doi.org/10.1139/X06-281

Morrissey, R. C., Jacobs, D. F., Seifert, J. R., \& Kershaw, J. A. (2010). Overstory Composition and Diversity of Naturally Regenerated Clearcuts at the Landscape-Scale in an Ecological Classification Framework. Plant Ecology, 208, 21-34. http://dx.doi.org/10.1007/s11258-009-9683-3

Mosseler, A., Lynds, J. A., \& Major, J. E. (2003). Old-Growth Forests of the Acadian Forest Region. Environmental Reviews, 11, S47-S77. http://dx.doi.org/10.1139/a03-015

Noble, I. R., \& Slatyer, R. O. (1980). The Use of Vital Attributes to Predict Successional Changes in Plant Communities Subject to Recurrent Disturbances. Vegetatio, 43, 5-21. http://dx.doi.org/10.1007/BF00121013

Nyland, R. D. (1996). Silviculture: Concepts and Applications. New York: McGraw-Hill.

Oliver, C. D. (1980). Forest Development in North America following Major Disturbances. Forest Ecology and Management, 3, 153-168. http://dx.doi.org/10.1016/0378-1127(80)90013-4

Oliver, C. D., \& Larson, B. C. (1996). Forest Stand Dynamics. New York: Wiley.

Ostrofsky, W. D., \& Houston, D. (1989). Harvesting Alternatives for Stands Damaged by the Beech Bark Disease. Proceedings of the 1988 Society of American Forester's National Convention, SAF Publication 88-01, 173-177.

Prager, U., \& Goldsmith, F. B. (1978). Stump Sprout Formation by Red Maple (Acer rubrum L.) in Nova Scotia. Proceedings of the Nova Scotian Institute of Science, 28, 1977-1978.

Rai, V. (2013). Spatial Ecology: Pattern and Processes. Beijing: Bentham Books.

Raymond, P., Munson, A. D., Ruel, J.-C., \& Coates, K. D. (2006). Spatial Patterns of Soil Microclimate, Light, Regeneration, and Growth within Silvicultural Gaps of Mixed Tolerant Hardwood-White Pine Stands. Canadian Journal of Forest Research, 36, 639-651. http://dx.doi.org/10.1139/x05-269

Ricklefs, R. E. (2004). A Comprehensive Framework for Global Patterns in Biodiversity. Ecology Letters, 7, 1-15. http://dx.doi.org/10.1046/j.1461-0248.2003.00554.x

Ridgeway, G. (2013). gbm: Generalized Boosted Regression Models. R Package Version 2.1. https://cran.r-project.org/web/packages/gbm/gbm.pdf 
Roberts, M. R., \& Gilliam, F. S. (1995). Patterns and Mechanisms of Plant Diversity in Forested Ecosystems: Implications for Forest Management. Ecological Applications, 5, 969-977. http://dx.doi.org/10.2307/2269348

Rowe, J. L. (1972). Forest Regions of Canada. Canadian Forest Service Publication 1300, Ottawa: Department of Environment.

Salonius, P. (2007). Silvicultural Discipline to Maintain Acadian Forest Resilience. Northern Journal of Applied Forestry, 24, 91-97.

Sexton, J. P., McIntyre, A., Angert, L., \& Rice, K. J. (2009). Evolution and Ecology of Species Range Limits. Annual Review of Ecology, Evolution, and Systematics, 40, 415-436. http://dx.doi.org/10.1146/annurev.ecolsys.110308.120317

Seymour, R. S., White, A. S., \& Demaynadier, P. G. (2002). Natural Disturbance Regimes in Northeastern North America -Evaluating Silvicultural Systems Using Natural Scales and Frequencies. Forest Ecology and Management, 155, 357367. http://dx.doi.org/10.1016/S0378-1127(01)00572-2

Simpson, J. (2009). Restoring the Acadian Forest: A Guide to Forest Stewardship for Woodlot Owners in the Maritimes. Halifax, NS: Res Telluris.

Smith, D. M., Larson, B. C., Kelty, M. J., \& Ashton, P. M. S. (1997). The Practice of Silviculture: Applied Forest Ecology (9th ed.). New York: Wiley.

Strong, T. F. (2005). Early Stand Development in a Red Oak-Paper Birch Stand Regenerated through the Shelterwood System in Northern Wisconsin. In D. R. Weigel, J. W. Van Sambeek, \& C. H. Michler (Eds.), Ninth Workshop on Seedling Physiology and Growth Problems in Oak Plantings (p. 19). USDA, Forest Service, North Central Research Station.

Strong, T. F., Hubbell, A. E., Weise, A. H., \& Erdmann, G. G. (2006). Effects of Crown Release on Growth and Quality of Even-Aged Red Maple Stands. Northern Journal of Applied Forestry, 23, 229-233.

Swanson, M. E., Franklin, J. F., Beschta, R. L., Crisafulli, C. M., DellaSala, D. A., Hutto, R. L. et al. (2011). The Forgotten Stage of Forest Succession: Early-Successional Ecosystems on Forest Sites. Frontiers in Ecology and the Environment, 9, 117-125. http://dx.doi.org/10.1890/090157

Swenson, N. G., Enquist, B. J., Pither, J., Kerkhoff, A. J., Boyle, B., Weiser, M. D. et al. (2012). The Biogeography and Filtering of Woody Plant Functional Diversity in North and South America. Global Ecology and Biogeography, 21, 798-808. http://dx.doi.org/10.1111/j.1466-8238.2011.00727.x

Taylor, A. R., \& Chen, H. Y. H. (2011). Multiple Successional Pathways of Boreal Forest Stands in Central Canada. Ecography, 34, 208-219. http://dx.doi.org/10.1111/j.1600-0587.2010.06455.x

Taylor, A. R., McPhee, D. A., \& Loo, J. (2013). Incidence of Beech Bark Disease Resistance in the Eastern Acadian Forest of North America. The Forestry Chronicle, 89, 690-695. http://dx.doi.org/10.5558/tfc2013-122

Trimble, G. R. J. (1973). The Regeneration of Central Hardwoods with Emphasis on the Effects of Site Quality and Harvesting Practice. Res. Pap. NE-282, USDA, Forest Service, Northeastern Forest Experiment Station.

Veblen, T. T. (1992). Regeneration Dynamics. In D. C. Glenn-Lewin, R. K. Peet, \& T. T. Veblen (Eds.), Plant Succession: Theory and Prediction (pp. 152-187). London: Chapman Hall.

Venables, W. N., \& Ripley, B. D. (2002). Modern Applied Statistics with S (4th ed.). New York: Springer. http://dx.doi.org/10.1007/978-0-387-21706-2

Walker, L. R., Wardle, D. A., Bardgett, R. D., \& Clarkson, B. D. (2010). The Use of Chronosequences in Studies of Ecological Succession and Soil Development. Journal of Ecology, 98, 725-736.

http://dx.doi.org/10.1111/j.1365-2745.2010.01664.x

White, P. S. (1979). Pattern, Process, and Natural Disturbance in Vegetation. The Botanical Review, 45, 229-299. http://dx.doi.org/10.1007/BF02860857

Williams, R. A., \& Heiligmann, R. B. (2003). Effects of Site Quality and Season of Clearcutting on Upland Hardwood Forest Composition 38 Years after Harvest. Forest Ecology and Management, 177, 1-10. http://dx.doi.org/10.1016/S0378-1127(02)00328-6

Zeide, B. (1999). Conceptual Issues of Ecosystem Management. Journal of Sustainable Forestry, 9, 1-20. http://dx.doi.org/10.1300/J091v09n01_01

Zelazny, V., Martin, G., Toner, M., Gorman, M., Colpitts, M., Veen, H., Godin, B., McInnis, B., Steeves, C., \& Roberts, M. (2003). Our Landscape Heritage: The Story of Ecological Land Classification in New Brunswick. Fredericton: New Brunswick Department of Natural Resources, Ecosystem Classification Working Group. 


\section{Submit or recommend next manuscript to SCIRP and we will provide best service for you:}

Accepting pre-submission inquiries through Email, Facebook, Linkedin, Twitter, etc A wide selection of journals (inclusive of 9 subjects, more than 200 journals)

Providing a 24-hour high-quality service

User-friendly online submission system

Fair and swift peer-review system

Efficient typesetting and proofreading procedure

Display of the result of downloads and visits, as well as the number of cited articles

Maximum dissemination of your research work

Submit your manuscript at: http://papersubmission.scirp.org/ 